\title{
チャ立枯症の品種間差異と幼木における地際部発根性
}

辳标水産省茶業試験場

鳥屋尾忠之・土井芳憲

\section{Varietal Differences of the Root Rot Disorder and Rooting \\ Property of Cutting Stem near the Surface of Soil in Young Tea Plant}

\author{
By Tadayuki TOYAO and Yoshinori DoI \\ National Research Institute of Tea
}

\section{1 まえがき}

チャの立枯症は，やぶさたの挿木苗による增殖が軌道 に乘り始めた，1963年（昭和38年）頃から各地て発生が 認められ，実態調査と原因の究明が行われた。艺の結果, 立枯症は新規開懇園の下層土の固、土㙴で発生が多く, また，定植後 3〜 5 年生溌生が集中していることが確 かめられた。さらに, 特定の土壌淀害, 線虫害の可能性 は少なく, 寒踣, 湿害, 施肥障害などの単独の障害でる ないと推定され，生理障害「立枯症状」として試験研究 が続けられた。

一方，当時の調查とその後静岡県下で行われた現地試 験, 発生事例の中で顕著な品種間差異のあることが明ら かにされ，また奻木に括ける根の形態，とくに地際部か らの細根発生と肥大についての品種間差異が観察され， これと立枯症との関連が指摘されている。

そこで，ここでは入手できる資料を集めて，主要品種 について立枯症の発生率の差異を集約して抵抗性の強弱 を整理し，また，幼水に括ける根の形態の品種間差翼を 明らかにしこれれにって立枯症抵抗性と，挿木苗なら びて幼木て括ける発根の形態のそれぞれの品種閒差異か ら，立枯症の発生機構解明の手がかり得ようとした。

な括，この報文は，農林水産省茶業試験場が参画した 特別研究「果樹等に括ける生理障害の解明と対策技術の 確立」のチャの立枯症に関する共同研究の一部である。

\section{2 チャ立枯症発生率の品種間差異}

チャの立枯症が注目されるようになった昭和 40 年代の 当初から，や方さた澄生が多いことが観察され，次い で行われた実態調査の中でもこの点が指摘された。をた，
他の品種についても，や充は（静岡），さやまみどり（滋 賀, 福岡)，たから酒（宫崎）に発生か認められている。 表 1 チャ立枯症発生の品種間差县 （1978，茶試枕崎支場）

\begin{tabular}{|c|c|c|c|c|}
\hline \multirow{2}{*}{ 品種 } & \multicolumn{3}{|c|}{ ブロック } & \multirow{2}{*}{ 平 均 } \\
\hline & $I$ & II & III & \\
\hline 拾くむさし & $0^{*}$ & $0^{*}$ & $0^{*}$ & 0 \\
\hline ゆたかみどり & 0 & 0 & 0 & 0 \\
\hline さや蓑かおり & 0 & 0 & 0 & 0 \\
\hline や类なみ & 0 & 0 & 0 & 0 \\
\hline はつもみじ & 0 & 0 & 0.5 & 0.17 \\
\hline やまとみどり & 0.5 & 0.5 & 0.5 & 0.50 \\
\hline ベにたちわせ & 0.5 & 0 & 1 & 0.50 \\
\hline あささつゆ & 0.5 & 1 & 0 & 0.50 \\
\hline $5 ん$ 加 & 1 & 1 & 0 & 0.67 \\
\hline 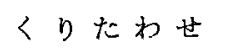 & 1 & 1 & 0.5 & 0.83 \\
\hline 茶本 NN 27 & 0.5 & 2 & 0.5 & 1.00 \\
\hline さやまみどり & 1.5 & 1 & 1 & 1.17 \\
\hline やまかい & 1 & 1 & 1.5 & 1.17 \\
\hline まきのはらわせ & 1 & 2 & 2 & 1.67 \\
\hline やぶきた & 2 & 2.5 & 1 & 1.83 \\
\hline$<ら d わ$ & 2 & 2 & 2 & 2.00 \\
\hline p充邼 & 2.5 & 2 & 2 & 2.17 \\
\hline するがわせ & 2 & 2 & 3 & 2.33 \\
\hline はつみどり & 2 & 3 & 3 & 2.67 \\
\hline (かなやみどり)** & 3 & 2 & 3 & 2.67 \\
\hline \multicolumn{5}{|c|}{ 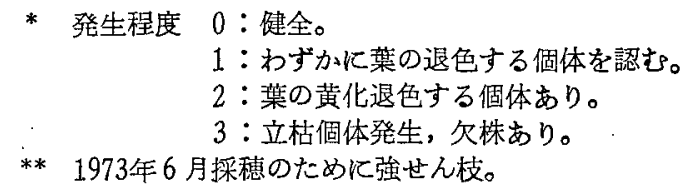 } \\
\hline
\end{tabular}

†本報の大要は茶業技術協会研究発表会 (Feb. 1983) に拈いて発表した。な掠，「立枯症」は，「立枯症状」 とよんでいたが，調査，研究が進むなかで，生理障害としての特性が明らかにされているので名称を改めた。 
しかし，多数の品種を供試した試験における発生事例は 少ない。そこてここでは，茶試枕崎支場に批りる観察結 果を示し，さらに各種の発生例を集約して立枯症に対す る品種の感受性を明らかにしようとした。

\section{1 枕崎支場における立枯症の品種間差異}

1971年 3 月に定植された品㮔見本園に㧍ける立枯症の 発生を，各ブロックごとに発生の全く認められない区を グレイド 0 とし，立枯れ枯株が発生した区を 3 とする 4 段階に分類し，立枯症に対する品種による感受性の差を 示した（表 1 )。

観察したのは，1978年 4 月であるが，症状の発生は定 植 4 年目から認められ，1975年，1976年に被害が目立っ た。

発生状況は，ブロック間の差は少なく，表にみられる とおり頟著な品種間差翼が観察された。いまグレイド 值の合計て品種の感受性を比較すると, 発生の多い品種 はやぶきたとその後代（かなやみどり，するがわせ， 吉 らさわ）の他に，はつみどり，や充は，まきのはらわせ があった。一方, 発生の全く認められない品種は, ゆた かみどり，やまなみ，さやまか扣り，拈くむさしであっ
た。な拈，さやまか拈りはやぶきたの自然実生から選坊 された品種であるが，やぶきたとは異なり発生率が少な いことは感受性の遺伝様式を考劣る上で閸味深い事実で ある。

\section{2 現地における立枯症発生の品種間差異}

前項でみられた品種間差異は，一定の条件下の 1 事例 にすぎない。そこて更に，品種比較のできる発生事例を 可能なかきり集めて，品種間差異を整理した（表 2)。

静岡県下の 5 地点の発生事例と，ここで取り上げたア ンケート調查に表われた立枯症発生の品種間差異は，表 1 の結果と同様に，やぶきたとその後代の品種の発生率 か高く，また同時に，达枯症の発生しない品種群のある ことも同様の結果である。さらに，枕崎支場では供試し なかったらじみどりはこのグループに入ると考えられ る。

ここでみられた発生率の差は，2種のアンケートにみ られた発生事例（この中の一部は，秋冬期に発生する裂 傷型凍害によるものる含まれている可能性すあるが）に おいても概ね一致している。ここで注目されるのは，静 岡県下で確かめられた発生率の品種間差異とさきの枕崎

林2 主要品種の現地に括ける立枯症発生率

\begin{tabular}{|c|c|c|c|c|c|c|c|c|}
\hline \multirow{3}{*}{ 品 } & \multicolumn{6}{|c|}{ 岡 * } & \multicolumn{2}{|c|}{ アンケート調査** } \\
\hline & 森 & 町 & 川 根 & 町 & 中川根町 & \multirow{2}{*}{$\frac{\text { 挂川市 }}{\text { 原 ノ谷 }}$} & \multirow{2}{*}{ A } & \multirow{2}{*}{ B } \\
\hline & 大 河 & 内 & 市尾 & 峯 & 地 名 & & & \\
\hline 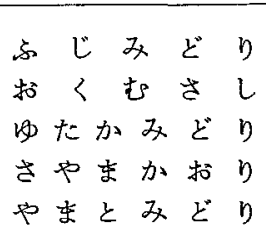 & $\%$ & $0^{\%}$ & $\begin{array}{l}0 \% \\
0 \\
0\end{array}$ & $\%$ & $\%$ & $\%$ & 1 & $\begin{array}{l}0 / 17 \\
0 / 13 \\
0 / 57 \\
0 / 47 \\
0 / 37\end{array}$ \\
\hline 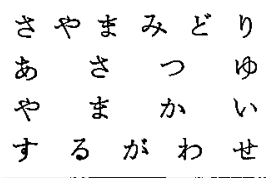 & & $\begin{array}{l}9 \\
7\end{array}$ & $\begin{array}{l}0 \\
2\end{array}$ & 0 & & 7 & $\begin{array}{l}2 \\
3\end{array}$ & $\begin{array}{l}2 / 62 \\
1 / 25 \\
0 / 39 \\
0 / 53\end{array}$ \\
\hline 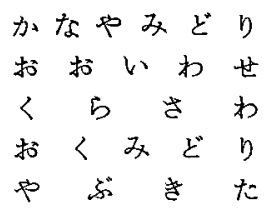 & $\begin{array}{r}7 \\
40 \\
60 \\
50\end{array}$ & 22 & 16 & 1 & $\begin{array}{r}3 \\
13 \\
\\
33 \\
3\end{array}$ & 18 & 2 & $\begin{array}{c}2 / 87 \\
\\
0 / 17 \\
5 / 24 \\
39 / 309\end{array}$ \\
\hline 調 查 年 月 日 & $\begin{array}{c}\text { 1981年 } \\
\text { 12月 }\end{array}$ & $\begin{array}{c}\text { 1974年 } \\
\text { 10月 }\end{array}$ & $\begin{array}{c}1966 \text { 年 } \\
12 \text { 月 }\end{array}$ & $\begin{array}{c}\text { 1966年 } \\
\text { 12月 }\end{array}$ & $\begin{array}{c}\text { 1982年 } \\
12 \text { 月 }\end{array}$ & $\begin{array}{c}\text { 1966年 } \\
12 \text { 月 }\end{array}$ & & \\
\hline 樹 & 4 年 & 6,4 年 & $2 \sim 10$ 年 & $2 \sim 17$ 年 & 4 年 & 2 年 & & \\
\hline
\end{tabular}

* 静岡県の発生率は, 木村, 大石, 鈴木, 日高, 此本; 静岡県茶試研報, No. 9 (1978) おるひび静岡県茶試試 験成績（昭和56，57年度）から計算し作表した。

** アンケ一ト調相 $[\mathrm{A}$ ：会議資料，農水省烟作振與課（昭和52年 2 月17日）の発生事例。 発生事例 [ $\mathrm{B}$ ：「品種アンケート取りまとめ」の中から抽出した発生事例/栽培事例。 
支場のそれとは恬添並行した結果が得られていることで ある。このことは, 東海地方から九州南部にかけて観察 されたこの立枯症が，同一の発生機構に基づくものであ ることを示唆している。

以上の結果と，表1にあげなかった一部の品種の現地 試験の結果を追加して立枯症に対する抵抗性とし, 主要

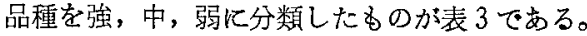

表 3 立枯症抵抗性の品種閒差罢

\begin{tabular}{|c|c|}
\hline 抵抗性 & 品 \\
\hline 強 & $\begin{array}{l}\text { らじみどり，やまなみ，おくむさし， } \\
\text { さやまか枋り，やまとみどり， } \\
\text { ゆたかみどり }\end{array}$ \\
\hline 中 & $\begin{array}{l}\text { さやまみどり，あさつゆ，やまかい， } \\
\text { やえほ，Z1，するがわせ，からべに， } \\
\text { たまみどり }\end{array}$ \\
\hline 弱 & $\begin{array}{l}\text { かなやみどり,くらさわ，おおいわせ， } \\
\text { 打くみどり，やぶきた }\end{array}$ \\
\hline
\end{tabular}

\section{3 幼木における地際部発根性の 品種間差是}

チャの挿木苗に捺ける発根位置と，地際部の紏根多発 に伴5肥大現象には, 品 㮔間差異のあることを前報で指 摘した。立枯症の発生の多いやぶきたは地際部の肥大現 象が顕著であり，一方，抵抗性品種ふじみどりは地際の 母茎部からの発根はみられないことから，立枯症の発生 と関係あるものと推定した。

ここでは，発根のタイプの品種閒差異を，定植 3 年目 の幼木について調查し，前報の挿木苗で得られた結果と の䦎で共通した傾向が認められるかどうかを確かめた。

\section{1 材料と方法}

1977年 6 月插しの 2 年生苗を，1979年 4 月茶試場内汪 場に定植し，1982年 4 月に掘り取り調查を行った。供試 品種は，やぶきた，ふじるどり等10品種である。

調查は，挿穂母茎部加らの発根とそれ伴 5 肥大に注 目し，地中に埋った母茎の上部からの細根発生の多少を， 調查個体ごとに，観察によって細根発生多を 3 ，全く発 生していないるのに 0 とする， $3 ， 2 ， 1 ， 0 の 4$ 種の 階級值を与えて示した。

また，母茎からの木化根の発達と，地中の母茎の上部， 中部，下部の直径を調査した。同時に，母茎と木化根の

表 4 奻木に括ける地下部母茎かららの発根の品種間差梖

\begin{tabular}{|c|c|c|c|c|c|c|c|c|c|c|c|c|c|}
\hline \multirow{3}{*}{ 品種 } & \multicolumn{7}{|c|}{ 母 荃 上 部 の 発 根 } & \multirow{2}{*}{\multicolumn{3}{|c|}{ 母荃の直径 }} & \multirow{2}{*}{\multicolumn{2}{|c|}{ TAC含量 }} & \multirow{3}{*}{$\begin{array}{l}\text { 調 查 } \\
\text { 個体数 }\end{array}$} \\
\hline & \multicolumn{5}{|c|}{ 細根発生の多少 * } & \multirow{2}{*}{ 木化根 } & \multirow{2}{*}{ 储考 } & & & & & & \\
\hline & 3 & 2 & 1 & 0 & 平均 & & & 上部 & 中部 & 下部 & 母茎 & 太根 & \\
\hline やぶをた & 62 & 38 & $\begin{array}{l}\% \\
0\end{array}$ & $\begin{array}{l}90 \\
0\end{array}$ & 2.6 & 19 & \begin{tabular}{|l} 
細根は上, 中 \\
部のみ
\end{tabular} & $\underset{19}{\mathrm{~mm}}$ & $\begin{array}{c}\mathrm{mm} \\
17\end{array}$ & $\mathrm{~mm}_{15}$ & 24.9 & 44.9 & 21 \\
\hline 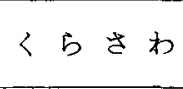 & 30 & 45 & 25 & 0 & 2.1 & 30 & $\begin{array}{l}\text { 木化根 } \\
\text { 中部㳄多、 }\end{array}$ & 18 & 22 & 20 & 30.3 & 40.2 & 20 \\
\hline かなやみどり & 21 & 50 & 29 & 0 & 1.9 & 54 & $\begin{array}{l}\text { 紐根 } \\
\text { 上部に多い }\end{array}$ & 19 & 18 & 16 & 27.3 & 38.8 & 24 \\
\hline たまみどり & 7 & 66 & 7 & 20 & 1.5 & 7 & $\begin{array}{l}\text { 細根 } \\
\text { 中部に多い }\end{array}$ & 17 & 20 & 21 & 33.9 & 39.5 & 15 \\
\hline さやまみどり & 10 & 25 & 60 & 5 & 1.4 & 45 & & 19 & 20 & 17 & 24.6 & 27.8 & 20 \\
\hline ゆたかみどり & 4 & 30 & 57 & 9 & 1.3 & 57 & 木化根多い & 16 & 19 & 17 & 3.8 & 5.8 & 23 \\
\hline からべに & 0 & 15 & 80 & 5 & 1.1 & 32 & $\begin{array}{l}\text { 木化根 } \\
\text { 中部に多い }\end{array}$ & 19 & 20 & 20 & 23.6 & 33.9 & 19 \\
\hline Z 1 & 0 & 22 & 65 & 13 & 1.0 & 26 & & 18 & 19 & 16 & 10.5 & 22.4 & 23 \\
\hline おくむさし & 0 & 8 & 56 & 36 & 0.7 & 12 & & 15 & 15 & 17 & 20.9 & 27.8 & 25 \\
\hline ふじみどり & 0 & 0 & 6 & 94 & 0.1 & - & & 20 & 20 & 23 & 15.5 & 31.5 & 17 \\
\hline
\end{tabular}

*: 発生の多 $(3)$ ～少 $(1)$, 無 (0) 
全可利用性炭水化物 (TAC) 含量を分析した。

\section{2 結果と考察}

母茎上部からの細根発生の多少を 4 段階て評価（表 4) すると,やぶきたは平均值2.62で最成細根の発生が多く, 次いでくらさわ2.05，かなやみどり成.92てあった。これ に反して，おくむさし0.72，ぶじみどり0.06は少ない。 そして，同じ母荠上部の木化根発生率も品種間差異は顕 著てやや゙きたは最す少ないグループに入り，かなやみど り，ゆたかみどりの発生率は高く50\%を越光ている。

また，この材料の母茎の上部，中央部，下部の径学 4 に示したが，いまこの径の大小のパターンによって供 試品種を分類した結果は次のと打りである。

$$
\text { I（上>中>下）やぶきた，かなやみどり }
$$

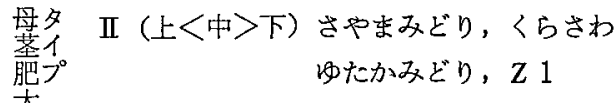

の III (上く中く下) たまみどり, からべに

IV（上＝中く下）报むさし，ふじみどり

このように，地際の母茎部の肥大のタイプは，これま での観察と同様に，定植後土に埋め込まれた母茎かららの 発根の多少, 特に母茎上部からの発根に伴ら肥大現象の 結果を反映していると考えられる。

また，TAC 含量にる䫓著な品種間差異が認められ， やぶきた，かなやみどり，等が高く特に，品たかみどり， Z 1 は低い值を示した。

以上のと扣り, 主要品種の邚木に括ける地際部発根性 は，発根が㨂穂母茎の上，中，下のいずれの部位に多い
か，発根した細根が早く木化根に発達するかどうか，ま た，細根の多発に伴5母荃の肥大がみられるかど5かな ぞによって，明らかな差異が観察された。

そこで,ここでみられた幼木における地際部発根性と， 既報の洀木苗 2 年生の発根の様相の品種間差異飞つい

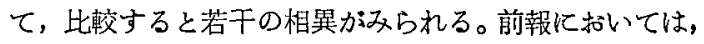
插木苗の型を母茎の発根部位によって分けると，やぶき たとふじみどりの両極端はよく一致した結果である。し かし，里たかみどり，Z1の2品種がやぶきたに近似し 母茎上部からの発根タイプになっているのが，異った結 果でる。そこて，前報の成績をこの 4 品種について， 母茎上部に扣ける細根・木化根の発生を抽出してまとめ

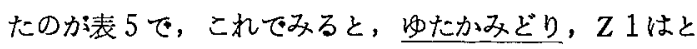
もに細根の量す多く，特にゆたかみどりは，母荃上部か らの細根量が多い。しかし, 同時に, この2 品種は木化 根子母茎上部加発生している。表 4 に名られると和り， 奻木のゆたかみどり，Z1の母茎上部からの細根発生の グレイドは, 1.29, 1.04 となって, やぶきた (2.62) よ りかなり低い值て，ふじみどり (0.06) との中間の值を 示す。このことから母茎上部からの発根の多い品種の中 にも，ゆたかみどり，Z1のように 2 年生苗から定植後 にかけて, 発生した細根が早く木化根に発達して, 定植 後 4 年を経たこの調査時点ては細根は少なくなったもの と考えられる。従って, 前報の插木苗に㧍ける品種閒差 異とこの幼木の品種閒差晎とは，このよ5な定植後の年 月の経過に伴ら変化とすれば矛盾はないるのといえる。

表 5 挿木苗 2 年生の母茎上部に批引る発根 (中山ら, 1977)

\begin{tabular}{|c|c|c|c|c|c|c|c|c|}
\hline \multirow[b]{2}{*}{ 品 } & \multicolumn{2}{|c|}{ 細 } & & \multicolumn{2}{|c|}{ 生 } & \multicolumn{3}{|c|}{ 木 化 根 の 発 生 } \\
\hline & 根 & $\begin{array}{c}\text { 細 眼 } \\
\text { (B) 重 } \\
\end{array}$ & $\mathrm{B} / \mathrm{A}$ & $\begin{array}{l}\text { 艇上部 } \\
\text { 紐 } \\
\text { 根重 } \\
\text { (C) }\end{array}$ & $\mathrm{C} / \mathrm{A}$ & 全 (D) 体 & $\begin{array}{c}\text { 母蕉上部 } \\
(\mathrm{E})\end{array}$ & $\mathrm{E} / \mathrm{D}$ \\
\hline やぶきた & $\begin{array}{c}\mathrm{g} \\
26.5\end{array}$ & $\begin{array}{r}\mathrm{g} \\
13.4\end{array}$ & $\begin{array}{l}\% \\
51\end{array}$ & $\begin{array}{r}\mathrm{g} \\
4.9\end{array}$ & $\begin{array}{l}\% \\
18\end{array}$ & $\begin{array}{c}\text { 本 } \\
4.3\end{array}$ & $\begin{array}{l}\text { 本 } \\
0.1\end{array}$ & $\begin{array}{r}\% 6 \\
3\end{array}$ \\
\hline ゆたかみどり & 24.8 & 10.4 & 42 & 3.6 & 15 & 4.1 & 0.7 & 16 \\
\hline Z 1 & 20.6 & 10.5 & 51 & 0.9 & 4 & 3.4 & 0.6 & 18 \\
\hline ふじみどり & 34.6 & 6.0 & 17 & 0 & 0 & 4.8 & - & - \\
\hline
\end{tabular}

\section{4 立枯症の品種間差異と地際部発根性}

現地での立枯症の品種間差異を，抵抗性の強，中，弱 の3グループに分け，これと，表4でみたそれぞれの品 種の母茎上部からの細根発生のグレイドと母茎肥大のタ イブI〜IV との関係を表したのが図 1である。

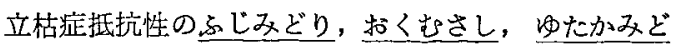
りの 3 品種は，それぞれ插穂母茎の上部からの細根発生 は少なく，抵抗性の弱いやぶき，〈らさわ，かなやみ દ゙りは細根が多発し，抵抗性中位の 4 品種は，細根の発 生も中間の值を示す。また，母菱の肥大のタイプとの関

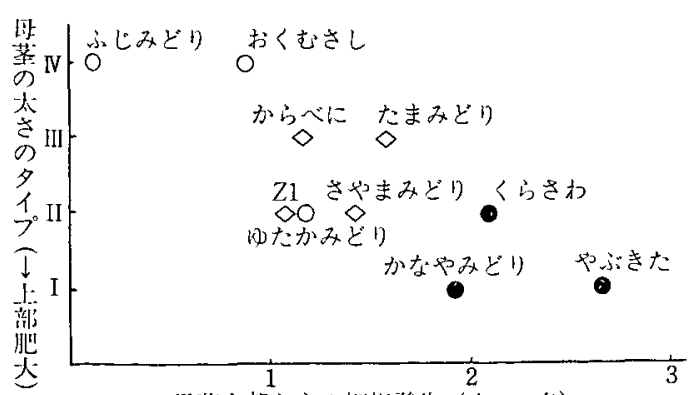

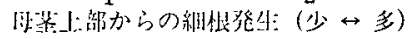

図 1 幼木の地際部発根性之立枯症抵抗性抵抗性 $\circ:$ 強, $\diamond:$ 中, $\bullet:$ 弱 
係も認められ，細根の多発仅肥大が伴い，このことから， 抵抗性との関わりが生じているものと考えられる。

以上の上5に，睍地での立枯症発生の多少（立枯症抵 抗性の強弱) と, 地際部の母荎上部からの細根の発生し 易さとの間には密接な関係があるものと推定される。

ここでみたように，やぶきた代表される，立枯症抵 抗性の弱い品種は，例外なく地際母茎部加の細根多発 型であり，また，発生した細根から木化根への発達が， 抵抗性品種よりる遅い品種であることがわかった。この ことは，立枯症の現地試験でも確かめられ，また，品種 閒の差の欢でく，同一品種でる苗の素質によって木化 根への発達のよい場合（一節苗网筒区等）には，立枯症 の初期症状とみられる細根，木化根の壊死が少ないこと す観察している。一方, 定植後幼木から成木に至る根群 の発達については, 詳細な観察が行われ, 細根発生から 次第に木化根の比率を增していく過程が明らかにされて いる。 5 年生て症状が叹られ，それ以降の発生は少ないこと， 地上部に症状のみられるよりす $1 \sim 2$ 年前に根の障害が 先行していることが報告されている。

以上のことから，定植後 $2 ， 3$ 年の, 根圈土境あるい は気象要因からのストレスを受け易い細根の比率の高い 幼木に抎ける根の障慧から，立枯症が始まっていると考 光られる。

「生理障害」特別研究の中で，立枯症発生要因を整理 し，次のような要因の相互関係を推定した。地際部細根 の発生し易い品種, 木化根への発達の遅い樹体要因を 「細根依存型」とし，これに加えられる「強せん枝」に

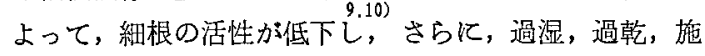
肥障害, 特殊養分の不足等の「根圈土境要因」がくり返 し重なることによって根の障害を招き，次いで地上部の 症状として表われて立枯れに至ると推定している。した がって，ここで取り上げている地際部発根性の品種間差 異は,この「細根伡存型樹体要因」を左右する最毛重要 な要因と考兑られる。

\section{5 摘 要}

チャ立枯症の発生の品種間差異と，幼木に拈ける挿穂 母茎の地際部発根性との関係を明らかにすることによっ て, 立枯症の発生機構解明の手がかりを得ようとした。

1）チャ立枯症の発生率には顕著な品種間差異が，品 種比較試験等で認められ，感受性品種はやぶきたとその 後代である招くみどり，かなやみどりであり，抵抗性品 種は灾じみどり，扰しさし，さやまか拉りであった。

2）地際部の母茎上部からの細根発生と，それに伴う 肥大には，主要品種の間で明らかな差異が認められた。 また，細根から木化根への発達の早遅にも品種間差異が
認められた。 細根が発生し易く，木化根への発達の遅れ る品種は, 立枯症の抵抗性が弱く, 逆に細根の発生の少 ない品種は，立枯症に対して概ね抵抗性を示した。

3）このような品種間差異から，幼木に打ける地際部 発根性は, 立枯症に関与する最も重要な要因の一つと考 えられた。

立枯症の発生率の品種間差異の集約に当って，未発表 の成績の引用を許可していただいた静岡県茶業試験場， ならびに，終始ご指導を賜った茶業䣳験場栽培部長中 山仰博士, 調査に協力を仰、だ枕崎支場 田中勝夫技官 (現：西富勝夫技师，山口県農林部)，根の形態調查試 料を提供していたたいた茶業試験場業務科に和礼を申し 上げる。

\section{6 文献}

1）資料：茶研報，No. 30，68～103 (1969).

2）広川 敢, 高屋茂雄: 茶研報, No. $30,11 \sim 18$ (1969).

3）広川 敢, 高屋茂雄：茶研報, No. $30,18 \sim 25$ (1968).

4）木村政美, 大石貞雄, 鈴木幸隆, 此本晴夫, 日高 保：静岡県茶試研報, No. 9，11３1（1978）.

5）中心仰，土井芳憲，石川洋子：茶研報，No. 48 , 16 22 (1978).

6) 茶関倸専門別総括検討会議, 育種部会: 茶技研, No. 62,76 (1982).

7) 酒井慎介: 茶技研, No, 36, 21 27 (1968).

8）青野英也，築瀬好充，田中静夫：茶技研，No. 56, 10 29 (1979).

9）青木 智, 鳥屋尾忠之: 茶研報, No. 58, 1 6, (1983).

10）土井芳憲, 鳥屋尾忠之, 青木 智: 茶研報, No. 59 , $7 \sim 12$ (1984).

\section{Summary}

To find out the cause of "root rot disorder", the relationships between the varietal differences in disorder and the rooting property of the upper part of cutting stem in young plants were investigated.

1) Varietal differences in disorder were detected clearly in the rates of occurrence in the several cultivar tests. The sensitive cultivars were 'Yabukita' and its families i.e 'Okumidori' and 'Kanayamidori', and the resistant ones were 'Fujimidori', 'Okumusashi' and 'Sayamakaori'. 
2) Distinct differnces in growth of fine roots from the upper part of underground region of the cutting stems and in thickening growth of the stems through the vigorous rooting were both observed among the main tea cultivars. And also the varietal differenee was shown in the developing rates of thick roots from the fine roots.

The cultivars which showed good rooting ability from the upper part of cutting stems and also showed slow growth of thick roots from the fine roots were estimated to be sensitive for the disorder, on the contrally, the poor rooting cultivars in that part of stems were generally resistant to the disorder.

3) According to the relationships among the above varietal differences, the rooting property in young tea plants on cutting stems near the soil was considered to be one of the most effective factor which directly controls this disorder.

(Oct. 4, 1983) 